\title{
A guinea-pig model of ultrasonically nebulized distilled water-induced bronchoconstriction
}

\author{
M. Fujimura, M. Amemiya, S. Myou, M. Mizuguchi, T. Matsuda
}

A guinea-pig model of ultrasonically nebulized distilled water-induced bronchoconstriction. M. Fujimura, M. Amemiya, S. Myou, M. Mizuguchi, T. Matsuda. (cERS Journals Ltd 1997.

ABSTRACT: Ultrasonically nebulized distilled water-induced bronchoconstriction (UNDW-IB) is specific to asthma. The mechanisms underlying UNDW-IB are not fully understood, and no reproducible animal model has been reported. The purpose of this study was to develop a guinea-pig model of UNDW-IB.

Ultrasonically nebulized distilled water (UNDW) was inhaled 20 min after an aerosolized antigen challenge in passively sensitized and artificially ventilated guineapigs. UNDW was also inhaled 5 and $20 \mathrm{~min}$ after $0.1 \mathrm{mg} \cdot \mathrm{mL}^{-1}$ methacholine inhalation in nonsensitized animals. In addition, $0.1 \mathrm{mg} \cdot \mathrm{kg}^{-1} \mathrm{~S}-1452$, a thromboxane $\mathrm{A}_{2}$ antagonist, or saline was given intravenously 5 min before UNDW inhalation in sensitized animals.

The inhalation of UNDW caused bronchoconstriction, when inhaled $20 \mathrm{~min}$ after an antigen challenge in sensitized guinea-pigs. UNDW inhalation did not produce bronchoconstriction after saline inhalation in nonsensitized or sensitized guineapigs, or after antigen inhalation in nonsensitized animals. Methacholine-induced bronchoconstriction did not evoke UNDW-IB. Neither did S-1452 reduce the UNDWIB. In conclusion, the guinea-pig model of ultrasonically nebulized distilled waterinduced bronchoconstriction developed in this study suggests that allergic reaction, but not bronchoconstriction, can induce bronchial hyperresponsiveness to ultrasonically nebulized distilled water, and that thromboxane $\mathrm{A}_{2}$ is not involved in ultrasonically nebulized distilled water-induced bronchoconstriction. Eur Respir J 1997; 10: 2237-2242
The Third Dept of Internal Medicine, Kanazawa University School of Medicine, 13-1 Takara-machi, Kanazawa 920, Japan.

Correspondence: M. Fujimura

The Third Dept of Internal Medicine Kanazawa University School of Medicine 13-1 Takara-machi

Kanazawa 920

Japan

Keywords: Allergic reaction guinea-pig thromboxane $\mathrm{A}_{2}$

ultrasonically nebulized distilled waterinduced bronchoconstriction

Received: February 181997 Accepted after revision July 31997

This study was supported in a part by Grant-in-Aid for Scientific Research (C) from The Ministry of Education, Science and Culture (07670662) of the Japanese Government.
Ultrasonically nebulized distilled water-induced bronchoconstriction (UNDW-IB) is highly specific for asthma [1-6], especially when compared to methacholine-induced bronchoconstriction [1-4].

Although some researchers have examined the mechanism underlying UNDW-IB, it is not fully understood. The development of an animal model of UNDW-IB may be helpful for understanding the mechanisms of UNDW-IB because procedures that can induce UNDWIB may clarify the mechanisms that cause it. Furthermore, the involvement of chemical mediators, the autonomic nervous system, tachykinins, and other cytokines in UNDW-IB can be examined using selective inhibitors that cannot be given to asthmatics. However, no reproducible animal model of UNDW-IB has ever been reported.

It has been stated that the inhalation of propranolol or of ultrasonically nebulized distilled water (UNDW) causes bronchoconstriction only in asthmatics [7, 8]. We previously reported a guinea-pig model of propranolol-induced bronchoconstriction [9], in which the inhalation of propranolol $20 \mathrm{~min}$ after antigen inhalation caused bronchoconstriction in passively sensitized guinea-pigs. Since specific inhibitors of thromboxane $\mathrm{A}_{2}\left(\mathrm{TxA}_{2}\right)$ [9] and platelet-activating factor (PAF) [10], but not sensory neuropeptides [11], significantly inhib- ited the propranolol-induced bronchoconstriction, we postulated that an allergic mediator mechanism was important in propranolol-induced bronchoconstriction.

Mormile et al. [12] have reported that a significant increase in bronchial reactivity to an ultrasonic mist of distilled water is observed after allergen inhalation in humans. UNDW-IB predominantly occurs in asthmatic patients with moderate-to-severe illness $[13,14]$. Asthmatic patients who have a positive response to UNDW have increased numbers of mast cells and eosinophils. as assessed by analysis of their bronchial tissue obtained by endobronchial biopsy [14, 15]. These findings suggest that a positive response to UNDW is related to the extent of allergic airway inflammation, and that the sensitization and presence of allergic inflammatory cells and/or mediators in the airways mediate UNDWIB. These findings prompted us to examine whether UNDW-IB can occur after an allergic reaction.

\section{Materials and methods}

Animals

Male albino Hartley strain guinea-pigs weighing 330-380 g were obtained from Sankyou Laboratory 
Service (Toyama, Japan). They were kept in conventional animal housing facilities for 1 week prior to use and were allowed to eat and drink ad libitum.

\section{Passive sensitization of guinea-pigs}

Guinea-pig homocytotropic antiserum was obtained by the method elaborated in SANTIVES et al. [16]. Briefly, $500 \mu \mathrm{g}$ of ovalbumin (OA) was emulsified in Freund's complete adjuvant and injected intradermally into each guinea-pig at multiple sites. A booster dose was prepared and administered in the same manner 2 weeks later. Serum collected from each animal 2 weeks after the booster dose was pooled, and kept frozen until use. The antibody titre of this serum was $1: 12,800$, $1: 6,400$, and 1:512, as estimated by passive cutaneous anaphylaxis at $4 \mathrm{~h}, 24 \mathrm{~h}$, and 7 days, respectively. Normal guinea-pigs were passively sensitized with $1.0 \mathrm{~mL} \cdot \mathrm{kg}^{-1}$ antiserum, i.p.

\section{Preparation of animals}

Five to 7 days after the passive sensitization, the guinea-pigs were anaesthetized with sodium pentobarbital $\left(75 \mathrm{mg} \cdot \mathrm{kg}^{-1}\right.$ i.p. $)$. They were placed in the supine position, and the trachea cannulated with a polyethylene tube (external diameter $2.5 \mathrm{~mm}$; internal diameter $2.1 \mathrm{~mm}$ ). The left jugular vein was cannulated for the administration of drugs.

After surgery, each guinea-pig was artificially ventilated by a small animal respiratory pump (Model 1680, Harvard Apparatus Co., Inc., South Natick, MA, USA). The tidal volume $(V \mathrm{~T})$ was $10 \mathrm{~mL} \cdot \mathrm{kg}^{-1}$, and the rate was 60 strokes $\cdot \mathrm{min}^{-1}$. The change in lung resistance to inflation, the lateral pressure of the tracheal tube (pressure at the airway opening; $P$ ao), measured in $\mathrm{cmH}_{2} \mathrm{O}$, was assessed using a pressure transducer (Model TP603T, Nihon Koden Kogyo Co., Ltd., Tokyo). As the change in $P$ ao following the inhalation of leukotriene $\mathrm{C}_{4}\left(\mathrm{LTC}_{4}\right)$ represents the average of the changes in pulmonary resistance $(R \mathrm{~L})$ and reciprocal dynamic lung compliance (1/Cdyn) [17], we used an increase in the $P$ ao as the overall index of bronchial response to bronchoactive agents.

When all procedures were completed, the lungs of the animals were over-inflated by twice $V \mathrm{~T}$ for two breaths by clamping the outlet port of the respirator. This resulted in uniformity of relative lung volume [18].

The aerosols used were generated for $30 \mathrm{~s}$ with an ultrasonic nebulizer developed for small animals at our institution [18]. The amount of aerosol produced when a physiological saline solution is nebulized is 15.2 $\mu \mathrm{L} \cdot \mathrm{min}^{-1}$ [19], and $46.4 \%$ of a nebulized albumin solution is deposited in the lungs when a $99 \mathrm{mTc}$-albumin solution is inhaled [18]. The median aerodynamic diameter of the particles of a physiologic saline solution is $3.59 \pm 1.96 \mu \mathrm{m}($ mean $\pm \mathrm{SD})$ when measured by a laser particle size analyser [19].

All the animal procedures in this study complied with the standards set out in the guidelines for the care and use of laboratory animals on the Takara-machi campus of Kanazawa University.

\section{Study protocol}

Study 1: UNDW inhalation in nonsensitized or sensitized guinea-pigs. Fifteen minutes from the start of artificial ventilation, when $P$ ao had stabilized, sensitized and nonsensitized animals were challenged with either UNDW or saline, without interrupting the constant ventilation ( $n=6$ in each group).

Study 2: UNDW inhalation after antigen challenge. When $P$ ao had stabilized 15 min after the surgical procedure, passively sensitized guinea-pigs were challenged with nebulized ovalbumin (OA) dissolved in physiologic saline $\left(0.1 \mathrm{mg} \cdot \mathrm{mL}^{-1}\right)$. Either UNDW $(\mathrm{n}=14)$ or saline $(\mathrm{n}=9)$ was inhaled for $30 \mathrm{~s}, 20 \mathrm{~min}$ after the OA provocation. In addition, UNDW $(n=8)$ or saline $(n=8)$ was inhaled $20 \mathrm{~min}$ after the $\mathrm{OA}$ challenge in nonsensitized animals.

Study 3: UNDW inhalation after methacholine-induced bronchoconstriction. To examine whether bronchoconstriction itself leads to UNDW-IB, UNDW $(n=6)$ or saline $(\mathrm{n}=6)$ was inhaled 5 and $20 \mathrm{~min}$ after $0.1 \mathrm{mg} \cdot \mathrm{mL}^{-1}$ methacholine was inhaled for $30 \mathrm{~s}$ by nonsensitized guinea-pigs.

Study 4: effect of salbutamol. A $\beta_{2}$-agonist, salbutamol $\left(5 \mathrm{mg} \cdot \mathrm{kg}^{-1}\right)(\mathrm{n}=9)$, or saline $(\mathrm{n}=9)$ was administered intravenously $15 \mathrm{~min}$ after the challenge with OA in passively sensitized guinea-pigs. UNDW inhalation was then performed 5 min later, 20 min after the OA challenge.

Study 5: effect of S-1452. To investigate whether TxA is involved in UNDW-IB, a specific TxA 2 receptor antagonist, $\mathrm{S}-1452$ [20], in a single dose of $0.1 \mathrm{mg} \cdot \mathrm{kg}^{-1}$ $(n=6)$, or saline $(n=6)$ was administered intravenously 15 min after the challenge with OA in passively sensitized guinea-pigs. UNDW was then inhaled 5 min later, $20 \mathrm{~min}$ after the OA challenge.

Chemicals. The following chemicals were used: distilled water and physiological saline (Otsuka Pharmaceutical Co., Ltd., Osaka, Japan); OA (Sigma, St. Louis, MO, USA); Freund's complete adjuvant (Sigma); sodium pentobarbital (Abbott Laboratories, North Chicago, IL, USA); salbutamol sulphate (Sigma); methacholine (Wako Pure Chemical Ind., Osaka, Japan); and S-1452 (Calcium 5(z)-1R, 2S, 3S, 4S-7- (3-phenylsulphonylaminobicyclo (2.2.1) hept-2-yl)-5-heptenoate hydrate) (Shionogi Pharmaceutical Ind., Osaka, Japan) [20].

\section{Statistical analysis}

Data are shown as the mean \pm SEM. Statistical differences were determined by unpaired t-test. Differences in the time course of the percentage increase in $P$ ao from the baseline value after provocation with OA or saline, or after the inhalation of UNDW or saline were analysed using a two-factor repeated analysis of variance (ANOVA). The time course curve after OA challenge or the inhalation of UNDW was compared between animals treated with salbutamol or saline, or with S-1452 
or saline by a two-factor repeated ANOVA. A pvalue of 0.05 or less was considered statistically significant.

\section{Results}

Study 1: UNDW inhalation in nonsensitized or sensitized guinea-pigs

The mean values ( \pm SEM) of the $P$ ao before the UNDW and saline challenge were 9.2 \pm 0.3 and $9.0 \pm 0.0 \mathrm{cmH}_{2} \mathrm{O}$ in nonsensitized guinea-pigs and $9.0 \pm 0.3$ and 9.2 \pm 0.4 $\mathrm{cmH}_{2} \mathrm{O}$ in sensitized guinea-pigs, respectively. There were no significant differences between these values. The percentage increase in $P$ ao after the inhalation of UNDW was not different from that after the inhalation of saline in both sensitized and nonsensitized guinea-pigs.

\section{Study 2: UNDW inhalation after antigen challenge}

The baseline $P$ ao values before the OA challenge were $9.4 \pm 0.2$ and $9.3 \pm 0.3 \mathrm{cmH}_{2} \mathrm{O}$ in passively sensitized animals given UNDW or saline, respectively. These values did not differ significantly. The peak $P$ ao values after the OA challenge were $223.5 \pm 22.7 \%$ with UNDW and $218.1 \pm 32.9 \%$ with saline (fig. 1). These values were not significantly different. The percentage increases in $P$ ao immediately before UNDW or saline inhalation (20 min after the OA challenge) were $210.8 \pm 19.5 \%$ and $218.1 \pm 32.9 \%$, respectively, and these values were not significantly different. Percentage increases in the $P$ ao at $1,2,3$, and $5 \mathrm{~min}$ after the inhalation of UNDW were significantly greater than those after the inhalation of saline $(\mathrm{p}<0.05)$ (fig. 1). UNDW inhalation did not cause a significant increase in the $P$ ao compared with saline inhalation, in nonsensitized guinea-pigs.

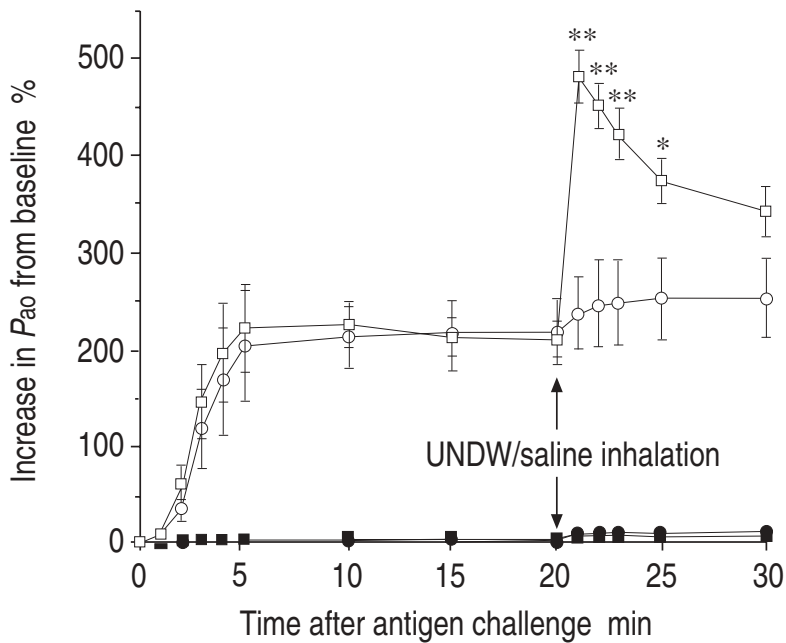

Fig. 1. - Time course of the percentage increase in pressure at the airway opening $(P$ ao $)$ after ovalbumin $(\mathrm{OA})$ challenge followed by inhalation of ultrasonically nebulized distilled water (UNDW) or saline $20 \mathrm{~min}$ after OA provocation in passively sensitized or nonsensitized guinea-pigs. Values are presented as mean+SEM. $\square$ : UNDW inhalation in passively sensitized animals $(n=14)$; $O$ : saline inhalation in passively sensitized animals $(n=9)$; $\boldsymbol{\square}$ : UNDW inhalation in nonsensitized animals $(\mathrm{n}=8) ; \bullet:$ saline inhalation in nonsensitized animals $(\mathrm{n}=8) . * * *: \mathrm{p}<0.05, \mathrm{p}<0.01$, compared with the passive sensitization and saline inhalation group.
Study 3: UNDW inhalation after methacholine-induced bronchoconstriction

Increases in $P$ ao from baseline values after the inhalation of either UNDW or saline, 5 and 20 min after aerosolized provocation with $0.1 \mathrm{mg} \cdot \mathrm{mL}^{-1}$ methacholine did not differ (fig. 2).

\section{Study 4: Effect of salbutamol}

The $P$ ao values before the OA challenge were $9.1 \pm 0.1$ and $9.0 \pm 0.3 \mathrm{cmH}_{2} \mathrm{O}$ in animals treated with saline and salbutamol, respectively. These values were not significantly different. The percentage increase in the $P$ ao 15 min after the OA provocation (just before the salbutamol treatment) was $200.3 \pm 27.5$ and $201.0 \pm 13.2 \%$ with saline and salbutamol, respectively. There was no significant difference between them. Compared with saline treatment, salbutamol reduced the percentage increase in $P$ ao and completely abolished the UNDW-induced increase in the $P$ ao (fig. 3 ).

\section{Study 5: Effect of S-1452}

The $P$ ao values before the OA provocation were $8.7 \pm$ 0.3 and $8.8 \pm 0.2 \mathrm{cmH}_{2} \mathrm{O}$ in animals pretreated with 0.1 $\mathrm{mg} \cdot \mathrm{kg}^{-1} \mathrm{~S}-1452$ or saline, respectively. These values were not significantly different. The peak values after the OA challenge were $205.3 \pm 24.3$ and $207.9 \pm 10.7 \%$ with saline and S-1452, respectively. These values did not differ significantly. The percentage increases in $P$ ao immediately before UNDW (20 min after the OA challenge) were $190.7 \pm 26.4$ and $162.7 \pm 11.6 \%$ in the groups given saline and S-1452, respectively. These values were not significantly different. The percentage increase in $P$ ao after the UNDW inhalation was not significantly different between treatment with S-1452 and treatment with saline (fig. 4). Similarly, when the percentage increase in the $P$ ao after UNDW inhalation and the value immediately before UNDW inhalation were compared, the time course curve did not differ significantly between treatment with S-1452 and treatment with saline.



Fig. 2. - Time course of the percentage increase in $P$ ao from the premethacholine value after the inhalation of UNDW $(n=9)$ or saline $(\mathrm{n}=9), 5$ and $20 \mathrm{~min}$ after aerosolized provocation with $0.1 \mathrm{mg} \cdot \mathrm{mL}^{-1}$ methacholine in nonsensitized guinea-pigs. $\bigcirc$ : saline inhalation; $\square$ : UNDW inhalation. For definitions, see legend to figure 1. 


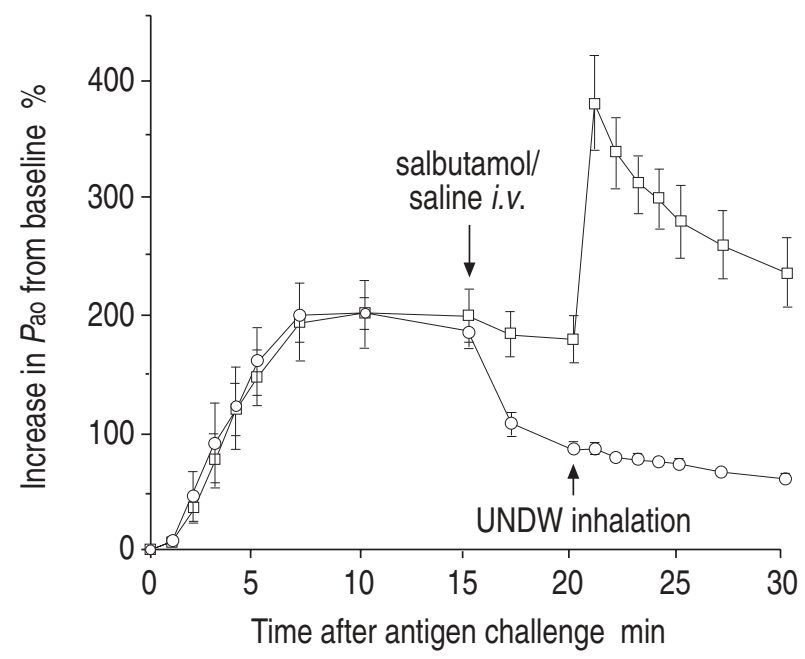

Fig. 3. - Time course of the percentage increase in $P$ ao after the inhalation of UNDW following OA challenge in passively sensitized guinea-pigs treated intravenously with saline $(n=9)$ or salbutamol $(n=9)$. O : salbutamol treatment; $\square$ : saline treatment. For definitions, see legend to figure 1 .



Fig. 4. - Time course of the percentage increase in $P$ ao after the inhalation of UNDW following OA challenge in passively sensitized guinea-pigs treated intravenously with S-1452 or saline 5 min before the UNDW inhalation (15 min after OA challenge). $O$ : treated with $0.1 \mathrm{mg} \cdot \mathrm{kg}^{-1} \mathrm{~S}-1452(\mathrm{n}=6)$; $\square:$ treated with saline $(\mathrm{n}=6)$. For definitions see legend to figure 1 .

\section{Discussion}

We examined whether the inhalation of UNDW can cause bronchoconstriction after antigen-induced bronchoconstriction in passively sensitized guinea-pigs. The study clearly demonstrated that bronchoconstriction occurred when UNDW was inhaled 20 min after challenge with an antigen in passively sensitized guinea-pigs. The inhalation of UNDW without an antigen prechallenge did not produce bronchoconstriction in either nonsensitized or sensitized guinea-pigs. In addition, methacholine-induced bronchoconstriction was not accompanied by UNDW-IB when UNDW was inhaled 5 or $20 \mathrm{~min}$ after the methacholine inhalation. These results suggest that an allergic reaction or process, excluding bronchoconstriction, may be one of the mechanisms underlying UNDW-IB. This proposal is compatible with several clinical studies showing that UNDW-IB is related to allergic reactions and the extent of airway inflammation $[14,15]$.

The $P$ ao measurement used in this study does not clearly distinguish between airway oedema and airway smooth muscle contraction. As the change in the $P$ ao, but not the absolute value of the $P$ ao, represents the average of changes in the $R \mathrm{~L}$ and $1 / C$ dyn when leukotriene $\mathrm{C}_{4}$ is inhaled [17], we have used ch.anges in the $P$ ao as an overall index of changes in airway calibre when oedema or inflammation of the lung parenchyma is negligible [9-11, 17-19]. UNDW inhalation caused an acute and sharp increase in the $P$ ao in the present study, suggesting the presence of bronchoconstriction but not airway oedema. In addition, we examined the effect of a bronchodilator, salbutamol, on the increase in the $P$ ao caused by UNDW inhalation. Salbutamol completely inhibited the UNDW-induced increase in the $P$ ao. It has been shown that intravenously administered salbutamol does not inhibit airway microvascular leakage induced by vagal stimulation [21], substance P [21], or platelet-activating factor [22], and that it has little or no inhibitory effect on histamine-induced microvascular permeability in proximal and distal intrapulmonary airways [23]. Taken together, it is likely that the increase in $P$ ao is indicative of bronchoconstriction induced by the inhalation of UNDW in our guinea-pig model.

We studied the effect of a $\mathrm{Tx} \mathrm{A}_{2}$ receptor antagonist, S-1452 [20], on UNDW-IB in the present animal model to determine whether $\mathrm{TxA}_{2}$ is involved in UNDW-IB. $\mathrm{TxA}_{2}$, a cyclo-oxygenase product of arachidonic acid metabolism, has been implicated in acute bronchoconstriction after antigen inhalation in asthmatic patients $[24,25]$, and this effect has been shown to be mediated by the stimulation of thromboxane receptors [26]. We have shown that $\mathrm{S}-1452$ reduces nonspecific bronchial hyperresponsiveness in stable asthmatic patients [27]. S1452 has been shown to antagonize the binding of ${ }^{3} \mathrm{H}-$ U46619 in washed rat platelets with stereo specificity and high potency (dissociation constant of the antagonist $(\mathrm{Ki}), 25 \mathrm{nM})$, but to have no inhibitory activity on the binding of ${ }^{3} \mathrm{H}$-prostaglandin $\mathrm{PGE}_{1},{ }^{3} \mathrm{H}-\mathrm{PGD}_{2}$, or ${ }^{3} \mathrm{H}-\mathrm{PGF}_{2 \alpha}$ to rat platelet membranes [20]. It has also been shown that S-1452 (100 nM) inhibits collagen-induced shape changes and aggregation of rat platelets [20]. The inhalation of propranolol causes bronchoconstriction only in asthmatics. We previously reported a guineapig model of propranolol-induced bronchoconstriction in which the inhalation of propranolol 20 min after antigen inhalation caused bronchoconstriction in passively sensitized guinea-pigs [9]. When S-1452, in doses of 0.01 and $0.1 \mathrm{mg} \cdot \mathrm{kg}^{-1}$, was given intravenously, $15 \mathrm{~min}$ after an antigen challenge, it completely inhibited the bronchoconstriction induced by propranolol inhaled 20 min after the antigen challenge in passively sensitized guinea-pigs [9], suggesting that an allergic mediator mechanism regulated propranolol-induced bronchoconstriction. In contrast, $0.1 \mathrm{mg} \cdot \mathrm{kg}^{-1} \mathrm{~S}-1452$ did not inhibit UNDW-IB in this study. These findings suggest that both UNDW and propranolol cause bronchoconstriction when they are inhaled after an allergic reaction, but that the mechanisms of action are different.

The inhalation of furosemide has been shown to inhibit the bronchoconstriction induced by UNDW [28, 29]. Shimizu et al. [30] have shown that it is possible 
that osmotic changes in periciliary fluid induced by UNDW cause rapid changes in ion transport or epithelial cell swelling. It has been postulated that water transport into the luminal side of the airway epithelium, or rapid cell swelling in small airways, may induce a transient fall in the forced expiratory volume in one second (FEV1) [30]. Sodium cromoglycate (SCG) is a well-established prophylactic drug for asthma, and this substance has been shown to inhibit mediator release from mast cells [31]. Nedocromil sodium also inhibits mediator release from mast cells [32]. Both drugs are effective in preventing UNDW-IB in asthmatics [1, 2, $33,34]$. These findings suggest that UNDW-IB may result in part from bronchoconstrictor mediators released from mast cells, such as histamine. We did not examine the effects of SCG and furosemide in the present study, as we considered SCG and furosemide to be inactive or less active in guinea-pig airways because of the following findings: it has been shown that SCG is inactive on tissue mast cells of the guinea-pig [35] and SCG does not inhibit respiratory distress caused by antigen inhalation in sensitized guinea-pigs [36]. Our previous study confirmed the lack of effect on antigen-induced bronchoconstriction in passively sensitized guinea-pigs (unpublished data), although nebulized furosemide has been shown to inhibit antigen-induced bronchoconstriction [37], but not histamine- or acetylcholine-induced bronchoconstriction [38], our previous study did not show an inhibitory effect of inhaled furosemide on antigen-induced bronchoconstriction in passively sensitized guinea-pigs (unpublished data). It has been postulated that furosemide inhibits cholinergic and excitatory nonadrenergic, noncholinergic neurotransmission [39], but our previous study showed that tachykinin is not involved in antigen-induced bronchoconstriction [40] or propranolol-induced bronchoconstriction after antigen challenge in passively sensitized guinea-pigs [11]. Future studies will be needed to assess the effects of these agents on our guinea-pig model of UNDW-IB.

In conclusion, we developed a guinea-pig model of ultrasonically nebulized distilled water-induced bronchoconstriction. This animal model is different from our animal model of propranolol-induced bronchoconstriction [9] regarding the role of thromboxane $A_{2}$. We believe that this is the first report of an animal model of ultrasonically nebulized distilled water-induced bronchoconstriction. Our model may be helpful for investigating the mechanism of one of the specific types of bronchial hyperresponsiveness in asthma.

Acknowledgement: The authors thank Shionogi Pharmaceutical Ind., Osaka, Japan for kindly supplying the S-1452.

\section{References}

1. Allegra L, Bianco S. Nonspecific broncho-reactivity obtained with an ultrasonic aerosol of distilled water. Eur J Respir Dis 1980; 61: 41-49.

2. Anderson SD, Schoeffel RE, Finney M. Evaluation of ultrasonically nebulized solutions for provocation testing in patients with asthma. Thorax 1983; 38: 284-291.
3. Galdes-Sebaldt M, McLaughlin FJ, Levison H. Comparison of cold air, ultrasonic mist, and methacholine inhalations as tests of bronchial reactivity in normal and asthmatic children. J Pediatr 1985; 107: 526-530.

4. Bascom B, Bleecker ER. Bronchoconstriction induced by distilled water: sensitivity in asthmatics and relationship to exercise-induced bronchospasm. Am Rev Respir Dis 1986; 134: 248-253.

5. Higenbottam T, Stokes TC, Jamieson S, Hill L. Bronchial reactivity in asthmatic adults with normal spirometric values. $\mathrm{Br}$ Med J 1983; 286: 1012-1014.

6. Schoeffel RE, Anderson SD, Altounyan RE. Bronchial hyperreactivity in response to inhalation of ultrasonically nebulized solutions of distilled water and saline. Br Med J 1981; 283: 1285-1287.

7. Zaid G, Beall GN. Bronchial response to beta-adrenergic blockade. N Engl J Med 1966; 275; 590-594.

8. Townly RE, McGeady S, Bewtra A. The effect of beta adrenergic blockade on bronchial sensitivity to acetylbeta-methacholine in normal and allergic rhinitis subjects. J Allergy Clin Immunol 1976; 57: 358-366.

9. Songur N, Fujimura M, Mizuhashi K, Saito M, Xiou $\mathrm{Q}$, Matsuda $\mathrm{T}$. Involvement of thromboxane $\mathrm{A}_{2}$ in propranolol-induced bronchoconstriction after allergic bronchoconstriction in guinea-pigs. Am J Respir Dis Crit Care Med 1994; 149: 1488-1493.

10. Fujimura M, Tsujiura M, Songur N, Myou S, Matsuda $\mathrm{T}$. Involvement of PAF in postallergic propranolol-induced bronchoconstriction in guinea-pigs. Eur Respir J 1996; 9: 2064-2069.

11. Fujimura M, Tsujiura M, Myou S, Ishiura Y, Matsuda T. Role of sensory neuropeptides in post-allergic propranolol-induced bronchoconstriction in guinea-pigs in vivo. Clin Exp Allergy 1996; 26: 1428-1435.

12. Mormile F, Mattoli S, Rosati G, Di Marzo A, Giappi G. Allergen-induced increase in non-allergic bronchial responsiveness to ultrasonic mist. Prog Resp Res 1985; 19: $256-265$.

13. Foresi A, Mattoli S, Corbo GM, Polidori G, Ciappi G. Comparison of bronchial response to ultrasonically nebulized distilled water exercise, and methacholine in asthma. Chest 1986; 90: 822-826.

14. Carpi S, Marini M, Vittori E, Vassali G, Mattoli S. Bronchoconstrictive response to inhaled ultrasonically nebulized distilled water and airway inflammation in asthma. Chest 1993; 104: 1346-1351.

15. Chetta A, Foresi A, Del Donno M, et al. Bronchial responsiveness to distilled water and methacholine and its relationship to inflammation and remodeling of the airways in asthma. Am J Respir Crit Care Med 1996; 153: 910-917.

16. Santives T, Roska A, Hensley GT, Moore VL, Fink JV, Abromoff P. Immunologically induced lung disease in guinea-pig. J Allergy Clin Immunol 1976; 57: 582-594.

17. Fujimura M. Inhibitory effect of steroids on slow reacting substance of anaphylaxis (SRS-A) mediated bronchoconstriction in guinea-pigs. Arerugi 1983; 32: 365-375.

18. Minami S, Okafuji K, Saga T, et al. A new quantitative inhalation apparatus for small animals. Nippon Kypbu Shikkan Gakkai Zasshi 1983; 21: 252-258.

19. Kurashima K, Fujimura M, Tsujiura M, Matsuda T. Effect of surfactant inhalation on allergic bronchoconstriction in guinea-pigs. Clin Exp Allergy 1997; 27: 337-342.

20. Hanasaki K, Arita H. Characterization of a new compound, $\mathrm{S}-145$, as a specific $\mathrm{TxA}_{2}$ receptor antagonist in platelets. Throm Res 1988; 50: 365-376.

21. Hui KP, Ventresca P, Brown AC, Barnes PJ, Chung 
KF. Modulation of neurally mediated airway microvascular leakage in guinea-pig airways by beta 2 -adrenoceptor agonists. Agents Actions 1992; 36: 29-32.

22. Boschetto P, Roberts NM, Rogers DF, Barnes PJ. Effect of antiasthma drugs on microvascular leakage in guinea-pig airways. Am Rev Respir Dis 1989; 139: 416421.

23. Advenier C, Qian Y, Koune JD, Molimard M, Candenas ML, Naline E. Formoterol and salbutamol inhibit bradykinin- and histamine-induced airway microvascular leakage in guinea-pig. Br J Pharmacol 1992; 105: 792-798.

24. Beasly RCW, Fetherstone RL, Church MK, et al. Effect of thromboxane receptor antagonist on $\mathrm{PGD}_{2}$ - and allergen-induced bronchoconstriction. J Appl Physiol 1989; 66: 1658-1693.

25. Manning PJ, Stevens WH, Cockcroft DW, O'Byrne PM. The role of thromboxane in allergen-induced asthmatic responses. Eur Respir J 1991; 4: 666-672.

26. Serio R, Daniel EE. Thromboxane and other inflammatory modulators of canine trachealis neuromuscular function. J Appl Physiol 1988; 64: 1979-1988.

27. Fujimura M, Nakatsumi Y, Nishi K, Kasahara K, Matsuda T. Involvement of thromboxane $A_{2}$ in bronchial hyperresponsiveness of asthma. Pulmonary Pharmacol 1995; 8: 251-257.

28. Robuschi M, Gambaro G, Spagnotto S, Vaghi A, Bianco S. Inhaled furosemide is highly effective in preventing ultrasonically nebulized water bronchoconstriction. Pulmon Pharmacol 1989; 1: 187-191.

29. Antonio F, Andrea P, Berardino M, Giampaolo C, Roberto MC, Luigi M. Effect of inhaled furosemide and torasemide on bronchial response to ultrasonically nebulized distilled water in asthmatic subjects. Am Rev Respir Dis 1992; 146: 364-368.

30. Shimizu T, Mochizuki H, Morikawa A, Kuroume T. Inhaled furosemide prevents ultrasonically nebulized water bronchoconstriction in children with both atopic and nonatopic asthma. Chest 1993; 104: 1723-1726.

31. Goose J, Blair AMJN. Passive cutaneous anaphylaxis in the rat, induced with two homologous reagin-like antibodies and its specific inhibition with disodium cromoglycate. Immunology 1969; 16: 749-760.

32. Wells E, Jackson CG, Harper ST, Mann J, Eady RP. Characterization of primate bronchoalveolar mast cells. J Immunol 1986; 137: 3941-3945.

33. Robuschi M, Vaghi A, Simone P, Bianco S. Prevention of fog-induced bronchospasm by nedocromil sodium. Clin Allergy 1987; 17: 69-74.

34. del Bufalo C, Fasano L, Patalano F, Gunella G. Inhibition of fog induced bronchoconstriction by nedocromil sodium and sodium cromoglycate in intrinsic asthma: a double-blind, placebo-controlled study. Respiration 1989; 55: $181-185$

35. Pearce FL, Al-Laith M, Bosman L, et al. Effects of sodium cromoglycate and nedocromil sodium on histamine secretion from mast cells from various locations. Drugs 1989; 37 (Suppl. 1): 37-43.

36. Armour C, Temple DM. The modification by ketotifen of respiratory responses to histamine and antigen in guinea-pigs. Agents Actions 1982; 12: 285-288.

37. Berti F, Rossoni G, Robuschi M, Mandelli V. Protective effect of furosemide combined with non-steroidal anti-inflammatory drugs administered by inhalation route on guinea-pigs anaphylaxis model. Arzneimittelforschung 1995; 45: 1098-1102.

38. Karlsson JA, Choudry NB, Zackrisson C, Fuller RW. A comparison of the effect of inhaled diuretics on airway reflexes in humans and guinea-pigs. $J$ Appl Physiol 1992; 434-438.

39. Elwood W, Lotvall JO, Barnes PJ, Chung KF. Loop diuretics inhibit cholinergic and noncholinergic nerves in guinea-pig airways. Am Rev Respir Dis 1991; 143: 1340-1344.

40. Mizuguchi M, Fujimura M, Amemiya T, Nishi K, Ohka $\mathrm{T}$, Matsuda T. Involvement of NK2 receptors rather than NK1 receptors in bronchial hyperresponsiveness induced by allergic reaction in guinea-pigs. Br J Pharmacol 1996; 117: 443-448. 